\title{
Public Attitudes in Canada Toward Unmarried Mothers, 1950-1996
}

\section{Susan Crawford}

ABSTRACT: Has the social stigma and shame once attached to unwed motherhood disappeared? A review of the Canadian popular press from 1950 to the present suggests that the stigma is now an economic one. This paper traces public attitudes toward unmarried mothers as viewed primarily through the pages of Maclean's and Chatelaine and concludes that, while the stigma now is mainly an economic one, the sense of shame surrounding unwed motherhood has not disappeared completely.

Her features are stained by shame and fear. Her body is distended by pregnancy. [To her family] Mariette is a fallen-woman-child who has injured herself and disgraced her family. To her society, Mariette is a many sided anomaly: outcast, pitiable unfortunate, moral lawbreaker, social problem. ${ }^{1}$

Mariette was a pregnant, unmarried young girl in Canada in the year 1959, one of 20,221 girls who gave birth to illegitimate children that year. ${ }^{2}$ This is not an insignificant number, but research shows that unwed mothers were treated as something even less than insignificant: usually the Canadian popular press did not treat them at all. The subject of illegitimacy was almost taboo in the Canadian press during the $1950 \mathrm{~s}$, and really only came out of the closet in the late 1960s and afterward. The image of the unwed mother as a 'moral lawbreaker' changed in the 1960 s to the unwed mother as a social problem. By the 1980 s, unwed mothers were divided into two quite distinct groups: the teenage, welfare-dependent girl who made a mistake, and the economically independent, older woman who made a choice. This paper attempts to deal with public

Past Imperfect, Vol. 6, 1997, pp.111-132 
attitudes toward unmarried mothers ${ }^{3}$ from the post-war era to today, and to explore the larger issues that such an examination raises. By studying a marginalized group such as unwed mothers, certain conclusions can be inferred about the social and moral attitudes of the larger society and the era in which they lived.

This paper will survey public attitudes toward unmarried mothers, by examining the writings of the Canadian popular press (eg. newspapers, Maclean's, Chatelaine, and Saturday Night, among others), from 1949 until 1996. It should be noted that drawing firm conclusions about public attitudes from the pages of magazines and newspapers is difficult. First, there is a distinct lack of information on the subject and what information is available cannot be taken to represent the views of society as a whole; and second, the literature seems to take a much more gentle, and liberal, view of the plight of the unmarried mother than does the 'man on the street.' Thus, a magazine like Chatelaine will report on the hostile reaction of neighbors to the opening of a group home for single mothers, while implying that the magazine does not share this reaction. ${ }^{4}$ Somewhere within this passive-aggressive reporting lies the true public attitude of Canadians to unwed mothers.

The image of Canada in the $1950 \mathrm{~s}$ is one of domesticated, conformist, suburbia. Babies were born at unprecedented rates and raised in families in which the sexual division of labor was rigid. Mom raised the kids according to the tenets of Dr. Spock, and Dad earned the living which brought them the much-valued suburban house, car, and other consumer accoutrements which signified success and well-being. This was the 'family decade.'5 Sex was supposed to take place within the sanctity of marriage and those who broke the rules, and got caught by getting pregnant, were stigmatized.

That is, the women were stigmatized-men were usually a forgotten or unspoken part of the equation. However, 
Maclean's published an article on the subject of unmarried fathers in 1949 and painted a generally sympathetic portrait. "The Forgotten Fathers," the title of the Maclean's article, is a fascinating reflection of public attitudes toward the roles of men and women. The article claimed that the public viewed the unmarried father as a 'low scoundrel' who had no sense of responsibility toward either "the unfortunate woman or the hapless infant" but that social workers had a different view of these men. "They say the unmarried father is not a 'professional wolf' or a criminal type. Chances are that he is a normal, personable youth extremely worried by the difficulty in which he finds himself." The article then went on to say that while many unmarried fathers were 'evasive and conscienceless,' just as many acted generously and honestly. Apparently, the appearance of some of the men as evasive and conscienceless was not what it appeared to be: "Often the father remains unknown simply because the woman cannot identify him [other than as] 'Al' or 'Bill' or 'a tall guy with red hair' that she met on the beach". The implication here was obviously one of moral laxity on the part of the woman, not the man. "Even more common are cases where the woman refuses to name the man because it may spoil her chances of marrying him later." This manipulativeness of women was another cross the unmarried father had to bear. ${ }^{6}$

While information on unwed mothers in the post-war era is scarce throughout the popular literature, at no time is there such a dearth as there was in the 1950s. Research turned up only two other articles dealing specifically with the unwed mother: one which showed a surprising liberal slant, and another which detailed the policies of a Montreal institution for unwed mothers.

While Saturday Night was considered a highbrow, intellectual, and left-leaning publication in the 1950's, an article written by Svanhuit Josie in 1950 entitled "The Unwed Mother... Her Right to Her Child," seemed almost 
provocative even for that magazine. Josie discussed a case, which went before the Supreme Court, in which an unmarried mother who had given her child to foster parents with a view to adoption, sued to have the child returned to her. The Court's decision was in favour of the mother and stated that when a child had not yet been legally adopted the natural mother had a right to its custody. Josie went on to say that mothers should not be forced to give up their babies but should be provided with financial assistance and day care by provincial governments. While this argument seems radical considering that the stigma attached to unmarried mothers was so strong, the article also reflected prevailing social beliefs. For example, Josie cited the fact that unmarried mothers may well get married in the future, thus eliminating the taint of illegitimacy from the child. The author also mentioned that "contrary to popular belief, the mother instinct is equally strong whether the mother is married or not." Apparently many Canadians felt that a wedding band bestowed not only respectability, but maternal instinct as well. ${ }^{7}$

The options available to pregnant, unmarried girls in the 1950 s were few. Abortion was illegal and to avoid the public shame an unmarried daughter would bring, many girls were sent away to relatives or to homes for unmarried mothers after which they would give their babies up for adoption. ${ }^{8}$ The maternity home offered secrecy and protection, and many offered personal redemption. While there is little information in the Canadian press about maternity homes, it is probably safe to assume that the mission of Canadian homes for unwed mothers was similar to that of American homes. Historian Rickie Solinger states that for the first half of the century the mission of these institutions was both charitable and punitive. But in the post-war era, homes were geared toward redeeming and transforming girls and setting them on the right tracktoward the feminine ideal of woman as wife and mother. ${ }^{9}$ 
This appeared to be the case in the Maclean's article entitled "The Happy Havens of Sister Mechtilde" which describeed the rehabilitation hostels of the Misericordia Sisters in Montreal. Sister Mechtilde was a Catholic nun who studied psychiatric social work and applied the principles she learned to the pregnant girls who were housed in the hostels. The article described how Sister Mechtilde viewed the girls as both "objects of fervent compassion and the raw material of a psychotherapeutic experiment"; the Sister's belief was that girls get pregnant due to the lack of love from a father. The hostel's attempts at rehabilitation included teaching the girls traditional feminine skills such as sewing, cooking, and ceramics. These attempts to restore self-respect were augmented by compassion, along with new psychiatric and sociological methods. ${ }^{10}$

While maternity homes such as those run by the Misericordia Sisters did offer a haven for many unmarried girls, and were no doubt run with the best of intentions, it also appears that the methods used in Sister Mechtilde's hostels added still another pejorative label to the unwed mother. Along with being an "outcast, pitiable unfortunate, moral lawbreaker and social problem," pregnant girls were also seen as psychiatric cases. ${ }^{11}$ Psychoanalytic theory was commonly used to explain unwed pregnancy and psychiatrists argued that the destiny of real women was that of wife and childbearer. Thus, those whose behavior denied this destiny were seen as having some sort of disorder or disease. The use of psychiatric science to explain unwed motherhood did provide a form of social protection in that the women were seen as vulnerable and in need of help, as opposed to being viewed as moral degenerates, but such theories also reinforced the idea that unwed mothers were mentally ill. ${ }^{12}$

The theme of unwed mother as mental patient continued in the popular press through the 1960 s and 1970s. The 
question of why women 'allowed' themselves to become pregnant was answered with psychiatric jargon. In a 1970 issue of Chatelaine, U.S. psychiatrists theorized that "out of wedlock pregnancy is an attempt to find a replacement for a "lost love object' and thereby ward off depression." The article went on to describe several women and explain why they got pregnant. Shana, described as 'The Brilliant Neurotic,' said she got pregnant because she subconsciously wanted to be punished for breaking the moral code she had been taught. Marnie, 'The Waif,' supposedly kept her baby in order to present her parents with a gift, and Catherine, 'The Straight Girl,' bought herself a wedding band and moved frequently out of fear the neighbors would find out she was a single mother. ${ }^{13}$

Journalist Simma Holt recruited the advice of experts on how to stop the flood of illegitimate births in her 1967 book, Sex and the Teen-age Revolution. Dr. David Claman felt that a wide gulf separated the generations, and to narrow this gulf and get the message across that illegitimacy was a huge social problem, he suggested that adults must quit sending messages in language the young 'do not dig.' Another expert said that people must quit searching for pleasure outside the family unit: "the day must return when the little girl bakes and cleans with her mother...and Dad and his son work in the garden and the workshed." Montreal's police chief stated that self-discipline was the answer, and had to be developed beginning at birth with parents refusing to spoil their babies. Overall the book suggests that the 'true family' provides inner strength and confidence and those born outside the 'true family' will always suffer "lonely hopelessness and moral difficulty."14 With the clarity of hindsight the advice of the experts seems smug and sexist, but within the context of the times Holt's book demonstrates prevailing attitudes toward teenagers and unwed mothers. 
While it might appear that with the advent of the swinging sixties tolerance of single mothers would have increased, this does not appear to be the case, at least within the pages of the national press. One Edmonton neighborhood, Pleasant View, appealed to the city development board that a group of five unwed mothers not be allowed to live there. As one of the Pleasant View residents said, "I'd rather have a bunch of Negroes living next door than tramps like this." The girls won the case, but the reasons behind the win reflect the condescending attitudes still in place: "I think it's preferable to encourage these young people to pull themselves up by their bootstraps than to see them fall by as deadwood," said one board member. ${ }^{15}$

While the number of women who made the choice to keep their babies in the sixties and seventies is unclear, what is clear is that the number of illegitimate births was increasing. From 1960 to 1970 , the percentage of illegitimate births rose from 4.3 per cent to 9.6 per cent. This percentage is greater than it appears: in 1960 the total number of live births in Canada was 478,551 with 20,413 of those described as illegitimate, but by 1970 the birth rate had fallen. Only 371,988 births were recorded, but of those 35,588 were illegitimate. ${ }^{16}$ It seems to be a paradox that illegitimate births were climbing at a time when birth control methods, particularly the Pill, were much more available to unmarried women than they had been before. ${ }^{17}$ However, the fact that birth control was available did not mean that people would use it. In a Chatelaine article entitled "Why Hasn't the Pill Stopped Illegitimacy?" the author claimed that "getting and using birth control means accepting one's sexual behavior and that is sometimes hard, given a lifetime of "moral conditioning." teenage pregnancy Ann Mason Swindlehurst said that in a society which values passive behavior in females, a girl must not plan sexual activity but must instead be "swept 
off her feet." This attitude did not allow for deliberate contraception. Also, ignorance of birth control methods was very high-many girls seemed to think that they were 'too young' to get pregnant, or believed that "you can't get pregnant the first time."19

Rickie Solinger said that the decision to keep their babies rather than give them up for adoption was mainly due to the sexual revolution wherein single mothers were no longer seen as abnormal, but rather as sexually active, independent young women. As unwed mothers "now exercised rights to their own sexuality, so did they exercise rights to their own illegitimate children." With the youth movement in full swing, behavior was judged more by one's peer group than by parents, thus removing much of the stigma from the unmarried mother, at least among those her own age. ${ }^{20}$

Despite the easing of public intolerance, the reality was that as she tried to raise her baby the unwed mother still faced overt discrimination from an older generation which still controlled housing and employment. Landlords and employers were reluctant to rent housing to, or hire single mothers. Landlords thought the woman would skip town without paying the rent and employers hesitated to hire single mothers, not through moral objections they claimed, but because she had to miss work any time her child was sick or the babysitter failed to show. ${ }^{21}$ The fact that this situation also held true for married mothers in the workforce is not mentioned in the literature. This shift from 'single mother as mental patient' to 'single mother as economic liability' begins to take hold in the 1970's, a trend which continues to the present time.

The economic reality of the single mother is a main thesis of the popular literature of the 1970 s. There is little censure of unwed mothers on moral grounds; rather, the articles discuss the issues surrounding the decision by pregnant girls to keep their babies. By 1976 the number of 
babies born out of wedlock to girls 15 to 19 years of age may have exceeded 19,000 and most of the mothers chose to keep their babies. ${ }^{22}$ There is little information available as to why women began to keep their infants rather than give them up for adoption. However, keeping an illegitimate child had lost the stigma it had in the 1940s and 1950s when relinquishing the child meant that mothers could put their mistake behind them. As public opinion changed, so did the pregnant girls' attitude toward themselves, and many felt little guilt over their situation. Chatelaine claimed that the approach of social agencies such as Children's Aid changed, and social workers began subtly influencing the girls to keep their babies. At the very least they were stressing the options available, so that the girl could make up her own mind. ${ }^{23}$ Another change which lessened the automatic stigma against unmarried mothers was a semantic one: with a rising divorce rate, the term 'single mother' no longer automatically meant 'unmarried' and, therefore, an immediate judgment could not be made.

As Maclean's pointed out, the young girls who chose to keep their babies were least prepared to support an infant, but they still had the legal right to make the decision to keep their babies. The decision to keep the child was usually based on the needs and wants of the mother and when a young mother found that her needs were not being met, but rather that the child was making constant demands on her, the problems became visible in the community. Without the financial, intellectual, or emotional resources needed to raise a child, the babies frequently became victims of neglect and abuse. In 1979, Children's Aid estimated that 20 per cent of teenage mothers who kept their babies gave them up for adoption within two years. The other 80 per cent would "keep Children's Aid in business. We'll see them in Family Services, in juvenile courts... and in prisons." ${ }^{24}$ Maclean's advocated legal 
intervention if neglect or abuse on the part of the mother could be proved, but pointed out that this would alter the country's social patterns. For example, after legal intervention who would become responsible for the child? The consensus between Maclean's and Chatelaine was that someone would have to step in to help the single mother, and in typical Canadian fashion, that someone was the government. The articles called for more low-income housing and making day care a priority, not as a solution to the problem but as a recognition of it. It should be pointed out that the Lane article in Chatelaine was one of the few which focused on what was best for the child rather than being concerned mainly with the mother. ${ }^{25}$

The idea that the stigma of unwed motherhood had lessened was reflected in a 1973 government of Alberta study entitled "Public Attitudes Toward Illegitimacy in Alberta." The study was done to determine whether or not public opinion favoured changing Alberta's illegitimacy laws, and to make recommendations for changes. The following table lists the various answers Albertans gave to the question, "From a moral point of view, what is your attitude toward the mother of an illegitimate child? (ONE ILLEGITIMATE CHILD ONLY)":

a) She has done something wrong and should suffer the consequences. $\quad 5 \%$

b) She has done something wrong but should not have to suffer harsh consequences.

c) She should not be blamed if she is a responsible mother.

d) She needs guidance counselling or psychiatric help.

e) It depends on her age.

f) There is nothing wrong with what she has done. 
g) It depends on other conditions. $\quad 3 \%$

h) Other response. $\quad 5 \%$

i) Don't know or no opinion. $\quad 4 \%$

With the majority of responses grouped around moderate alternatives $(b, c, f)$, it seems that public attitudes toward unmarried mothers in Alberta were fairly understanding and tolerant. ${ }^{26}$

While the idea of stigmatizing unwed mothers on moral grounds was outdated by the 1970 s, the 1980 s saw an increasing emphasis on the unwed mother (particularly the teenager), and her child as social problems. Planned Parenthood estimated that in 1982, 1,050 teens were getting pregnant each week in Canada, and of those who took their pregnancy to term, approximately 80 per cent chose to raise their babies on their own. ${ }^{27}$ The result was "a social problem of unprecedented dimensions." Problems for the mother included poverty, foreshortened education, marital breakdowns, and medical problems. Problems for the infant included health difficulties and a much higher chance of suffering from abuse and neglect. ${ }^{28}$

Poverty among unwed mothers was the norm. With little education, and few job skills, teenage mothers settled for low-paying, menial work, or dependence on the welfare system. In 1983 the number of female single parents living below the poverty line in Canada was 49 per cent. ${ }^{29}$ The reality of having a baby did not square with adolescent fantasies: the image of the laughing mother and baby living in a house with a white-picket fence ${ }^{30}$ usually translated into an exhausted mother living in a tiny apartment she could not afford and working at a menial job or on welfare. While teenagers talked bravely about returning to school and establishing careers, the reality was that there was no money for babysitters, no places in subsidized day care, and the chronic exhaustion of dealing with a baby 24 hours a day. ${ }^{31}$ 
The majority of teenage mothers who gave birth before the age of seventeen never finished high school. "Adolescent parenthood is a problem because it often precedes the completion of education and securing of employment. Of all single parent mothers in Canada in 1984 who had children under 3 , only $29 \%$ were employed." 32 Lack of education meant the chances of a mother ever finding rewarding and satisfying work which paid an adequate income were slim.

Chatelaine reported that the most disastrous option for the pregnant teen was marrying the father of the baby. Again, the fantasy and the reality were poles apart:

[After the decision to marry] there follows a short happy period of excitement-a ring, showers, stag party, wedding. Nobody pays any attention to such key issues as how this household will be supported. She has no skills; she works a few months at a gas bar, a doughnut shop. He leaves school, takes whatever work's available. She begins to feel rotten, loses interest in sex (which was not all that interesting to begin with). They're falling behind on the rent, the furniture payments, the car insurance. The baby arrives, keeps them up nights. He begins to drink heavily, they fight, he beats her up, she leaves. Marriage proves, in short, not a solution to pregnancy but another trap..$^{33}$

While the reality was obviously not always as dire as the passage above makes out, nonetheless, the teenage divorce rate was two to three times as high as the rate for those who married in their twenties. ${ }^{34}$

Many of the medical problems faced by teenage mothers are a result of the denial of the pregnancy and a subsequent lack of prenatal care. Daniel Baum claimed that the syndrome of pregnancy denial was common, and in some girls it was extreme. Although younger mothers have no 
inherent health disadvantages, the lack of proper nutrition and good medical care can result in increased health problems, premature births, difficult deliveries, and lowbirthweight babies. ${ }^{35}$ The baby born to the teenage mother who has not had proper prenatal care and nutrition is frequently born prematurely, with associated health problems. Statistics from 1986 indicate that infant mortality for children born to mothers younger than 18 , was two to two and one-half times higher than that of the general population. These children also suffered more health problems in the first year of life such as gastrointestinal problems, accidents, and a higher incidence of sudden infant death. ${ }^{36}$

However, the greatest risk for the infant, and the greatest social problem which stems from teen pregnancy, is abuse and neglect. When the decision to keep her baby is made, and the young mother discovers that her needs are not being met, or her fantasies realized, she may not have the emotional or intellectual resources to deal with the demands that come with child-raising at the best of times, never mind being young, alone, and poor. The problem of child abuse among teenage mothers is large; various sources state that 50 per cent of abuse and neglect cases occur in households headed by young, single mothers. ${ }^{37}$

Statistics such as this are always controversial, and there are certainly some teenage mothers who raise happy and healthy children even under undesirable circumstances. However, children raising children in an impoverished environment with little support is a reality, and Chatelaine discussed possible solutions to the problem of adolescent pregnancy in its October 1982 issue. One extreme view was to make abortion and welfare less accessible, the idea being that if kids knew the consequences of their actions they would think twice before going ahead. Another view took the opposite tack, suggesting that Canadians offer full support to the unwed mother and accept that 
adolescence is just one part of a woman's life when she might choose to have children. Most experts' views were somewhere in between and focused on the idea that certain services should be provided to the young unmarried mother. These services included prenatal care, information on sex education and contraception, and keeping pregnant girls in school while offering a curriculum tailored to their needs. However, the article went on to say that society's best hope was prevention, and advocated more family planning services and sex education. ${ }^{38}$ Are these solutions to the problem of adolescent pregnancy? It does not seem likely; as mentioned earlier in this paper, the fact that the Pill existed did not mean everyone took it. Thus, the fact that prenatal care, education, and contraceptive counseling were available does not mean that they would be utilized.

One area addressed in this article was about an issue which is in the Canadian and American press frequently these days: the idea that teenagers deliberately get pregnant in order to receive welfare. At the risk of sounding sexist, this idea sounds like it may have come from some morally upright politician whose gender assures that he will never have to experience the reality of living the welfare highlife while raising a howling baby. As Dallas Petroff, executive director of Toronto's Planned Parenthood says, "Young girls do not get pregnant because they think they'll be eligible for mother's allowance or a free abortion. They're not thinking at all."39

Thus, it appears that public perception of unwed pregnancy in the 1980 s was that it had become a public problem as opposed to a private shame. In fact it was a public problem since, with the majority of mothers keeping their babies, welfare rolls and incidents of child abuse and neglect increased. The problems of teenage pregnancy are self-perpetuating with children of welfare mothers often becoming a second generation of welfare parents. ${ }^{40}$ 
The focus of media articles after 1984 changed from the problems of adolescent pregnancy to exploring an unprecedented trend taking place among single women: planned unmarried pregnancy. While the media still decried the rising birth rate of teenage mothers, and viewed the situation as a social problem, planned single motherhood was depicted far differently. It would be going too far to say that the media approved of the new trend, but there was certainly no hue and cry over the fact that women were deliberately choosing to have children and raise them without fathers. The tone of the articles was certainly far less judgmental than the tone used in discussing teenage pregnancy and unplanned single motherhood.

It appears that for the educated and economically independent woman who chooses to have a child on her own, there is little if any stigma attached. Certainly there is no sense of moral outrage, just a musing about the effects of raising a child without a father. In a Maclean's article entitled "A Declaration of Female Independence," the phenomenon is related to the feminist movement, and to the more traditional theory that women have special needs. "There is such a thing as an internal bubbling, an arousal, a tug for a baby that is an instinctual desire to reproduce," claimed one academic. Another disagreed: "What we are seeing is simply the reality that women have become independent." The article described three women who have fulfilled their dreams of motherhood, and discussed the reasons they chose to keep their children. All had a longstanding desire for motherhood, and two of the three had the economic independence to carry the decision through. The women described a need which they wanted to fulfill, and hoped that the love they felt for their children would compensate for any sense of loss the child may experience. ${ }^{41}$

While Maclean's took an objective view to planned single motherhood, Chatelaine was more openly positive: 
As options have opened for women, they've not only won control over unfettered reproduction. Their growing financial, social and emotional independence has gained them the freedom to reproduce if they want to, without the permission of men. ${ }^{42}$

For most women who choose single motherhood, their emotional relationships with men have not lived up to their expectations, and all the women in the article claimed that even if 'Mr. Right' came along, there was not enough room in their lives for him.

How did these women justify raising a child without a father, and how would they explain their decision to their children? Dr. Anne Eriksen, who conceived her child through artificial insemination, was not worried about male role models since she planned to spend annual holidays with her father and brothers who would be important influences on her son. When asked how she would explain her son's origins, she said, "It would be difficult for me...to have a tie with a person that I didn't want a tie with. I'd far rather say to my son, 'You have no father."' The women stressed that since the children were wanted children, that should make up for the problems they might face without having a father. The sense that men are superfluous pervaded each woman's story, as does the sense that they were determined to take advantage of all the new choices open to them. ${ }^{43}$ In their determination to leave no personal need unfulfilled, the planned child of a single mother can sometimes sound like another project to be fitted into a busy life.

The trend toward planned single motherhood seems to have increased in the 1990s. While there are no firm statistics, the Vancouver Sun claims that the birth rate among single, college-educated women in their thirties has tripled over the past decade. ${ }^{44}$ Public attitudes (as viewed through the eyes of the popular press) toward single 
women who plan their children seem to be more accepting albeit with a few timid qualms about the further breakdown of the 'traditional family.'

However, attitudes toward the stereotypical unwed mother (young, uneducated, welfare-dependent) are still that they constitute a social problem, which in fact they do. Just because a woman has the choice to keep and raise a child, does not mean that she should exercise that choice. While, again, statistics are hard to come by, the Vanier Institute states that there is no 'epidemic' of teenage pregnancy as is often mentioned in the press. Nonetheless, the number of children born outside marriage has doubled in the last decade, and many of those births were to economically disadvantaged teenagers. ${ }^{45}$ This is an ongoing problem and, in the U.S. at least, drastic measures have been proposed. One measure is to take mothers off welfare after two years, or deny them welfare if they are teenagers, and send their children to orphanages. While such measures seem draconian, a majority of the U.S. public supports them, since other measures have not worked. Margaret Wente, in the Globe and Mail described how other attempted solutions have failed:

Make the fathers pay? The fathers can't. Job training? Very expensive, not very effective, and there aren't any jobs anyway (except, maybe, in the orphanages). How about free contraception and self-esteem classes, so that poor teenage girls will have better goals than motherhood? It doesn't work. Most young single moms are not college material and will never have the kind of jobs that give life purpose and meaning. From their point of view, having a baby who will love them is a supremely rational decision. ${ }^{46}$

Wente observed that U.S. opinion leaders are trying out the idea of sin again, in an attempt to return to the ideas of 
'values,' and 'character.' While she said that putting fear and guilt back into young girls is a terrible thing, the alternative, i.e. single motherhood, is worse. It will be interesting to see if Canadians follow this lead, and if so, what the result is.

Perhaps shame and guilt should not be goals, and should not be seen as solutions. It seems likely that, as earlier in the century, girls would be censured while boys would not. Developing and instilling in children a sense of personal and societal responsibility when they are still children, while not a solution, might at least be a step in the right direction. Since the trend of unmarried mothers keeping their babies began one thread has run through all the research: when asked why they chose to keep their babies all the mothers including those who planned their pregnancies said, "Because I wanted to". The personal pronoun ' $I$ ' was the over-riding factor in their decisions, and while older mothers often gave more thought to the child, they too chose to have the child for personal fulfillment.

The reasons given by pregnant teenagers for keeping their babies center around personal wants: giving up the baby would be too painful for them; being a mother would make their life more interesting; and since getting pregnant was the mother's fault, the baby should not be punished by being given up for adoption. ${ }^{47}$ The last reason seems to demonstrate that while these girls are trying to appear mature by taking responsibility for their mistake, they still have not thought about what is best for the child, and in fact have no idea what is best. In a society which emphasizes personal fulfillment, it is difficult to blame a young girl for thinking that since she wants a baby, she should have one.

It is significant that legal discrimination against illegitimate children has been abolished in Canada, with the exceptions of Nova Scotia and Alberta. 
In Canada, all of the provinces and territories have legislation that significantly improves the status of children born outside of marriage. Indeed, all provinces and territories, except Nova Scotia and Alberta, have legislatively abolished the status of "legitimacy" and have declared legal equality between children, regardless of the marital status of the child's parents. ${ }^{48}$

The report cited above acknowledged that the abolition of illegitimacy was necessary in order to reflect current societal values, and to protect the human rights of children. This legislation ensures that children of unmarried mothers cannot be legally discriminated against, and is obviously a positive step toward erasing any remaining social discrimination which sometimes devolves onto the children of unmarried mothers, as well as the mothers themselves. ${ }^{49}$

Is the moral stigma of unwed pregnancy truly gone? Do girls no longer have any sense of shame or fear when they discover they are pregnant? A young woman at a Lutheran college in Camrose was charged with infanticide in January 1997 after killing her newborn baby. The woman had kept her pregnancy secret from all her family and all her friends. Why would she feel she had to do that? Was her fear so great? One can only speculate, but apparently it was. To go to such drastic measures, to hide a pregnancy, and then kill the baby indicates that while an increased acceptance of unwed pregnancy is the rule, there are always exceptions. What is comforting is that the response of the college was very compassionate; in a college run on moral and religious guidelines, a hard stand taken against the student would not have been surprising. The chaplain voiced the thoughts of many when he said that he wanted to turn the clock back and change "whatever it was that would not let her speak." He also spoke of the need to "better face our sexuality and to look at a world where women and children are way down the line of priorities." 50 
This example seems to suggest that bringing back shame and guilt to unwed mothers is not a solution. The fact that young women can still feel enough shame, fear, and guilt to cause them to deny a pregnancy and kill an infant should make that obvious.

It would appear that the stigma against unmarried mothers is now mainly an economic one-if a woman is financially capable of raising a child on her own, the attitude seems to be that she should go ahead and be fulfilled. If on the other hand, a 16-year-old girl chooses to raise her child and live on welfare, she is part of a large social problem and is deliberately putting herself and her child at risk. Both of these views have some truth. The majority of teenage mothers do depend on welfare, and taxpayers are justifiably getting angry about supporting children who often become part of a vicious cycle of poverty. And while the children of economically advantaged mothers will have more opportunities than welfare children, is it fair to deliberately choose to raise a child without a father? In the decades prior to the 1960 s, it was usually the mother who suffered from having an illegitimate child and the child was given up for adoption; in the decades since, it seems it is more often the child who is disadvantaged by being raised in socially and financially disadvantaged environments.

NOTES

1 Ken Lefolh, "The Happy Havens of Sister Mechtilde," Maclean's, 24 October 1959, 20, 66

. Statistics Canada, Historical Statistics of Canada (2nd ed., 1983), B1-14.

${ }^{3} \mathrm{I}$ am looking only at women who were unmarried at the time of their children's birth, not at divorced, widowed, or separated women.

${ }^{4}$ Bonnie Buxton, "The Single-Mother Subculture," Chatelaine, February 1970, 72.

${ }^{5}$ Doug Owram, Born at the Right Time: A History of the Baby- 
Boom Generation (Toronto: University of Toronto Press, 1996), $136 .{ }^{6}$ Sidney Katz, "The Forgotten Fathers," Maclean's, 1 May $1949,9$.

'Svanhuit Josie, "The Unwed Mother...Her Right to Her Child," Saturday Night, 15 August 1950, 26, 27.

${ }^{8}$ Owram, Born at the Right Time, 264.

${ }^{9}$ Rickie Solinger, Wake up Little Susie. Single Pregnancy and Race Before Roe V. Wade (New York: Routledge, 1992), 105106.

${ }^{10}$ Lefolh, "The Happy Havens of Sister Mechtilde," 66-69.

11 Ibid., 66.

${ }^{12}$ Solinger, Wake Up Little Susie, 86, 87, 102.

${ }^{13}$ Buxton, "The Single-Mother Subculture," 72.

14 Simma Holt, Sex and the Teen-age Revolution (Toronto: McClelland and Stewart, 1967) 160-163.

${ }^{15}$ Buxton, "The Single-Mother Subculture," 70.

${ }^{16}$ Historical Statistics, B1-14.

${ }^{17}$ Owram, Born at the Right Time, 267.

${ }^{18}$ Rosemary Lane, "Why Hasn't the Pill Stopped Illegitimacy?," Chatelaine, October 1973, 112.

${ }^{19}$ Ann Elizabeth Mason Swindlehurst, Teenage Pregnancy: Examining Differences Between 'Adopters' and 'Keepers', (Ph.D. diss., University of Alberta, 1986), 23.

${ }^{20}$ Solinger, Wake Up Little Susie, 217, 223.

${ }^{21}$ Buxton, "The Single-Mother Subculture," 73.

${ }^{22}$ Brenda Rabkin, "Despair That Breeds Despair," Maclean's, 5 February 1979, 37-38.

${ }^{23}$ Lane, "Why Hasn't the Pill Stopped Illegitimacy?," 112, 113.

${ }^{24}$ Rabkin, "Despair That Breeds Despair," 37-38.

${ }^{25}$ Lane, "Why Hasn't the Pill Stopped lllegitimacy?," 32, 112, 113.

${ }^{26}$ Michael Manley-Casimir, Research Coord., Public Attitudes Toward Illegitimacy in Alberta, Alberta Health and Social Development, 1973, 34.

${ }^{27}$ Fredelle Maynard, "Teen-age Mothers, A Nationwide Dilemma," Chatelaine, October 1982, 91, 126. Of those 1,050 pregnancies, no firm statistics are available regarding outcomes, i.e.whether the pregnancy ended up in miscarriage, therapeutic abortion, or adoption. Abortion statistics are not accurate due to regional inequity in reporting, and lack of data.

${ }^{28}$ In Trouble...A Way Out, A Report on Pregnancy and SexuallyTransmitted Diseases in Alberta Teens, May 1987, 31.

${ }^{29}$ In Trouble...A Way Out, 31.

${ }^{30}$ This appears to be a common image which comes up again 
and again. In Swindlehurst's thesis, she asked young mothers how they would accomplish this dream; all the girls replied that they would get married.

${ }^{31}$ Maynard, "Teen-age Mothers, A Nationwide Dilemma," 128. ${ }^{32}$ In Trouble...A Way Out, 32.

${ }^{33}$ Maynard, "Teen-age Mothers, A Nationwide Dilemma," 128. ${ }^{34}$ In Trouble...A Way Out, 31.

${ }^{35}$ Daniel Jay Baum, Teenage Pregnancy (Don Mills: General Publishing, 1980), 33-35.

${ }^{36}$ In Trouble...A Way Out, 30.

${ }^{37}$ Sources include Maclean's, 5 February 1979, "In Trouble...A Way Out," 1987, Baum, Teenage Pregnancy.

${ }^{38}$ Maynard, "Teen-age Mothers, A Nationwide Dilemma," 129.

${ }^{39}$ Maynard, "Teen-age Mothers, A Nationwide Dilemma," 128. ${ }^{40}$ Baum, Teenage Pregnancy, 27.

41 Robert Block, "A Declaration of Female Independence," Maclean's, 15 October 1984, 66.

${ }^{42}$ Suzanne Zwarun, "Singles Who Choose Motherhood," Chatelaine, August 1985, 62.

${ }^{43}$ Zwarun, "Singles Who Choose Motherhood," 62, 92-95.

${ }^{44}$ Alicia Priest, "Single Mothers: Bringing up Baby (Alone)," The Vancouver Sun, 21 January 1995, E17.

45 The Vanier Institute of the Family, Profiling Canada's Families (1994), 58-59.

${ }^{46}$ Margaret Wente, "The Troubling Increase in Single Motherhood," The Globe and Mail, 17 December 1994, A2.

${ }^{47}$ Swindlehurst, Teenage Pregnancy, 96.

${ }^{48}$ Law Reform Commission of Nova Scotia, The Legal Status of the Child Born Outside of Marriage in Nova Scotia, Final Report 1995, 13.

49 The Legal Status of the Child..., p. 6. The abolition of the status of illegitimacy took place in Ontario in 1977, with the other provinces following suit between 1980 and 1991.

${ }^{50}$ Helen Plischke, "Hundreds Mourn Dead Baby at Camrose College," Edmonton Journal, 1 February 1997, no page. 